\title{
Return to the Client: On the Contemporary Search for the Meaning of Social Work ${ }^{1}$ Michal Opatrný, Monika Flídrová, Anna Sýkorová
}

In the professional discourse of social work it is at present common to speak of a crisis of social work consisting in the blurring of its identity, in that social work is in fact done by unqualified workers, in loss of social prestige of social work, but allegedly also in weakening of the social state and decreasing state expenditure on the system of state guaranteed social assistance. With respect to the specific situation of Czech social work and the contemporary devaluation of the concept of crisis Baláž following Jan Sokol therefore proposes to speak of the misery of social work in the Czech context. ${ }^{2}$ In this context it is especially noted that in its current Czech form, framed by the systems of social services and social benefits, social work has slipped somewhere before the beginnings of its constitution as a self-contained field of human activity and scholarship. ${ }^{3}$ In the postmodern social context, for which it is characteristic that social risks are still produced by society but their solution is unlike the modern period privatized, there ultimately come considerations of the gradual termination of social work - the social context and within it especially the material provision for the realisation of social work by means of a system of social services is becoming a stifling blanket for it. ${ }^{4}$

In connection with current social problems the question is also raised if social work has not failed. And this is not a media or even tabloids topic initiated by the failure of an individual or the system, but a polemic of social workers in scholarly press. ${ }^{5}$ Issues are therefore discussed with utmost seriousness which perhaps just a few years earlier would not have been raised at all, focusing on the identity of social work. ${ }^{6}$ Of course, effort at its grounding has been here since last century. First (1920s-1960s) it manifested itself in the literature with an effort to defend the professional character of social work in connection with defining possible models of assistance. Later (since 1980s to present) authors focus on the issue of orientation and goals of social work. Precisely for this reason Payne defines the three well-known conceptions of the field - (1) therapeutic (supporting the self-realization of individuals or groups), (2) transformational (i.e., change of society in relations to the socially needy) and (3) striving for stabilization of the order -, in which social work fulfils its vocation to head towards the improvement of social conditions. ${ }^{7}$ The identity of social work has thus even received a separate entry in the recently published (2013) Encyclopaedia of Social Work. There Libor Musil conceives the

\footnotetext{
1 This study is an output of the project of specific research 117/2013/H Pojetí kvality sociální práce v souvislosti se sebedefinováním sociálního pracovnika a jeho profese solved at the Faculty of Theology, University of South Bohemia in České Budějovice.

2 Cf. Roman BALÁŽ, Možnosti dosahování oborových zájmů sociální práce v organizacích zaměstnávajících sociální pracovníky, Sociální práce/Sociálna práca 3/2014, pp. 45-46.

3 Cf. Libor MUSIL, Tři pohledy na budoucnost sociální práce, in: Rizika sociální práce, ed. Martin SMUTEK - Friedrich W. SEIBEL - Zuzana TRUHLÁŘOVÁ, Hradec Králové: Gaudeamus, 2010, pp. 11-25.

4 Cf. Oldřich CHYTIL, Důsledky modernizace pro sociální práci, Sociální práce/Sociálna práca 4/2007, pp. 64-71.

5 Cf. Česká sociální práce jako obor naprosto selhala: Rozhovor Jany Kopřivové s Janem Syrovým, Sociální práce/Sociálna práca 3/2009, pp. 7-9; Radka JANEBOVÁ, Selhala skutečně sociální práce jako obor?, Sociální práce/Sociálna práca 3/2010, pp. 35-37.

6 Cf. Roman PORČ, Smysl v práci pracovníka terénní sociální práce s uživateli nealkoholových drog. Master thesis defended at FSS MU in Brno in 2013. Thesis supervisor Stanislava Ševčíková; Jana VAŠíČKOVÁ, Interpretace role sociálního pracouníka v ženské věznici a její prožívání sociálními pracovnik $y$. Master thesis defended at FSS MU in Brno in 2013. Thesis supervisor Libor Musil; ( Pojetí kvality sociální práce v souvislosti se sebedefinováním sociálního pracovníka a jeho profese. Project of specific research of the Grant Agency of University of South Bohemia no. 117/2013/H, department of ethics, psychology and charity work at TF JU in České Budějovice. Head of team Markéta Elichová (on-line), at: http:/ / gaju.jcu.cz/grantova-agentura-ju-pro-rok-2013/TeamProjects, retrieved on February 27 2015.

7 Cf. Malcom PAYNE, What is Professional Social Work?, Bristol: BASW, 2006, pp. 12-20.
} 
professional identity of social work as "...collective self-conception of a group of people who regard as desirable to follow the goals of social work and act in ways specific for it." 8

Similarly in social discourse social work is regarded as a field with blurred status and vague meaning. ${ }^{9}$

At the same time it is characteristic of questions concerning the identity of social work that they do not deal with the question of the loss of meaning of the worker's own activity, with which the assisting professions are confronted. The present study therefore wants to grasp the question of meaning and identity of social work differently. On a detailed reflection of the sources of the crisis or misery of social work's identity it shows that together with the search for identity of social work its orientation on client is lost. But precisely the measure of client-orientation determines to what extent social work will or will not be meaningful.

\section{Crisis of meaning in contemporary social work discourse}

The above indicated crisis or misery of social work, or its identity and meaning, can be operationalized better based on contemporary Czech professional discourse. As already mentioned in the introduction, at least in the Czech context the cause of loss of meaning of social work is seen in the present manner of financing social work by means of the system of social services. But at the same time we can identify other sources of the crisis of meaning in the professional discourse. These are especially the real conditions in which social work is carried out, as well as definition of social work itself.

\subsection{Definition of social work}

The results of research within the project whose output this study also is have shown that "...the missing visible and clearly delimited result" of work leads in some social workers "... to frustration and loss of certainty in understanding the mission and identity of social work" ${ }^{10}$ The cause of this frustration may be precisely what is, or is not, regarded as social work.

Although Czech social work possesses a great number of its own definitions, only some of them can really be used not only to support the client that she may comply with the requirements of her social environment, but also to defend the clients' rights: "Work with the causes of problems and influencing the conditions of the environment in which the clients live is not customary in this country. A result of such fixation of social work can be the 'silence' of social workers, who actually need not regard the defence of clients' rights as part of the mission of their profession." 11 On the other hand, the prevailing definitions of social work outside the context of the Czech Republic derive from problems in interactions between humans and problems conditioned by socio-cultural difference. ${ }^{12}$ The problem of defining social work thus in fact deepens its own crisis. If the cause of the client's problems is primarily in her environment but the social worker does not regard influencing the environment's demands on the client as

\footnotetext{
8 Libor MUSIL, Identita oboru / profese sociální práce, in: Encyklopedie sociální práce, ed. Oldřich MATOUŠEK, Praha: Portál, 2013 , p. 512.

9 Cf. Libor MUSIL, Challenges of Postmodern Institutionalisation for Education in Social Work, in: Social Work, Education and Postmodernity: Theory and Studies in Selected Czech, Slovak and Polish Issues, ed. Tatiana MATULAYOVÁ - Libor MUSIL, Liberec: TUL, 2013, p. 10.

10 Martina PAJMOVÁ - Markéta ELICHOVÁ, Role osobnosti a edukace pro kompetence sociálních pracovníků, Sociální práce/Sociálna práca 4/2014, p. 104.

11 Radka JANEBOVÁ - Marcela HUDEČKOVÁ - Romana ZAPADALOVÁ - Jana MUSILOVÁ, Příběhy sociálních pracovnic a pracovníků, kteří nemlčeli - Popis prožívaných dilemat, Sociální práce/Sociálna práca 4/2013, p. 68.

12 Cf. Roman BALÁŽ, Možnosti dosahování oborových zájmů sociální práce, p. 44.
} 




social work, her work with the client eventually comes to naught. ${ }^{13}$ Czech legislation in fact does not even assume that social workers should also defend the rights of their clients. Only the Ethical Code of Social Workers of the Czech Republic in fact speaks on the issue, which however is not a formally overarching professional code. ${ }^{14}$ Point 2.5 of this code implicitly speaks of defending client's rights when it states that social workers ought to prompt changes in legislation, point out possibilities of a juster division of social resources and broaden the possibilities of improving the clients' quality of life. ${ }^{15}$

Janebová, Hudečková, Zapadalová and Musilová also point out that even such publication as the Encyclopaedia of Social Work in fact prefers the therapeutic conception of social work: "We have come to understand that a number of the encyclopaedia entries is written exclusively from the perspective of case work with client, preferentially aimed at adapting the client to the conditions of the social environment." The authors therefore believe that educational institutions in social work in the Czech Republic, from which most of the encyclopaedia's authors come, do not even envisage other conceptions of social work than the therapeutic one, or that they do not envisage initiating changes on the part of the client's social environment. ${ }^{16}$

A further source of the weakening of the identity of social work with respect to its definition can also be the unclarity and ambiguity of some concepts with which persons in social work commonly operate. E.g. in the $4^{\text {th }}$ issue of Sociální práce from 2014, which dealt with the issue of social justice, we can find several academic papers pointing out the ambiguity of the concept of social justice. But the Code of the Social Workers of CR mentions social justice besides human rights as one of the main sources of social work. The whole terminological concept is probably most poignantly expressed here: "While in the sphere of social rights the codes refer mainly to international human right documents and the Charter of Basic Rights and Freedoms, in the sphere of social justice they have nothing to lean on and rely on a certain intuition and perhaps even matter-of-factness of the understanding of the concept 'social justice'."17 This matter-of-factness with which the understanding of other concepts is quite commonly assumed in social work can certainly be due to the very practical orientation of social work, as well as its multidisciplinarity. The blurring of borders of the definitions of one and the same concept in various humanities and social sciences on which social work draws eventually results in everyone assigning some broad interdisciplinary meaning to the concept in question. But this paradoxically need not have anything in common with the original meaning of the concept in the individual fields, and thus also with why it was applied to social work.

\subsection{System of social services}

The identity of social work in CR was unintentionally threatened also by law 108/2006 Sb. The law is commonly understood as a breakthrough norm which has given a firm legislative and social framework to social work. But it only regulates one of the segments in which social work is carried out, i.e., social services. ${ }^{18}$ But as the same time a substantial part of social work

13 Cf. Libor MUSIL, Challenges of Postmodern Institutionalisation, p. 10, pozn. 2.

14 Defence of clients' rights in CR is discussed by ratified international contracts (e.g. convention on rights of persons with health handicap, convention on rights of child), reports of ombudsman, charter of rights and freedoms, standards of quality of social services etc., i.e., documents also regarded as points of departure of social work, but at a more general level than professional ethical codes.

15 Cf. Radka JANEBOVÁ - Marcela HUDEČKOVÁ - Romana ZAPADALOVÁ - Jana MUSILOVÁ, Př́běhy sociálních pracovnic a pracovníků, pp. 68-69.

16 Cf. ibid., p. 81.

17 Roman MíČKA, Sociální spravedlnost a lidská práva v sociální nauce církve, Sociální práce/Sociálna práca 4/2014, p. 84.

18 Cf. Anna SÝKOROVÁ - Markéta ELICHOVÁ, Kompetence sociálního pracovníka: co učí školy a co vyžadují zaměstnavatelé, Sociálnî práce/Sociálna práce 1/2015, supported by GAJU no. 117/2013/H, p. 2. 
is financed through this segment, with the result that only providing social services is regarded as social work. Law 108/2006 Sb. as such therefore does not cause the described problem, since in $\S 1$ par. 2 it among others explicitly states that it only regulates social work insofar as it is realized in social services.

In the course of 2014 this phenomenon was paradoxically even strengthened together with the fact that from January $1^{\text {st }}, 2015$ financing social services at regional level was introduced. The distribution of means to individual social services is determined by regional authorities, who should be better aware than the Ministry of Work and Social Affairs CR what services need to be supported in the region or its part. But at the same time this situation helps to bring about that social services are supported quite purposefully according to what target group they are aimed at. Thus services destined for the elderly or the handicapped have greater priority than services for the minorities or the homeless. It is a purely political calculation, when financing or not financing certain services is intended to attract or not turn off voters of the present regional coalition. Subsidiary financing of social services can thus paradoxically lead to quite contrary effects than the ones for which it was introduced. ${ }^{19}$

This and similar subordination of social work to social policy, or party social policy and momentary political interests, and "fitting" social work into the system of providing social services can eventually result in social workers' feeling that social work no longer is what they envisage it to be. It is no longer concerned with helping the client, but rather with offering unified products to a service applicant. The relationship with the client is thereby maximally regulated, which as a consequence means its formalization, which leads to routine in the worse sense of the word. Social workers then also e.g. state that the administrative agenda and context in which they must work is more stressing for them than the life situation and person of the client. ${ }^{20}$

In consequence of the described problems linked with the system of social services and their financing there occurs the following phenomenon: "Although social work has primarily individually ethical aspirations, it is at the same time realized in the complex political framework of the modern social state and social policy. But this is usually external to the motivation horizon of the social worker and her operation possibilities, whereby this individually-ethical motivation gets into tension towards the institutional surroundings." ${ }^{21}$ Although the author of this quotation is critical of this tension and appeals to social workers to have greater political understanding for the social state, with respect to the above described reality and its dark corners, as described by the study of Janebová and her colleagues cited above, it is evident that social workers rather face the challenge of protecting "their" professional interests, or protecting the professional interests of social work.

\subsection{The professional interests of social work vs. reality}

In the professional discourse of social work its professional interests are commonly and in fact quite matter-of-factly regarded as a matter of consensus of social workers: "The professional interest of social work in organizations is the need of social workers that such working condi-

19 Cf. Radka JANEBOVÁ - Marcela HUDEČKOVÁ - Romana ZAPADALOVÁ - Jana MUSILOVÁ, Př́iběhy sociálních pracovnic a pracovníků, p. 81.

20 Cf. Viviene E. CREE, The Changing Nature of Social Work, in: Social Work: Themes, Issues and Critical Debates, ed. Robert ADAMS Lena DOMINELLI - Malcolm PAYNE, Hampshire: Palgrave, 2002, p. 26.

21 Jakub JINEK, Sociální spravedlnost pro sociální práci, Sociální práce/Sociálna práca 4/2014, p. 36. 


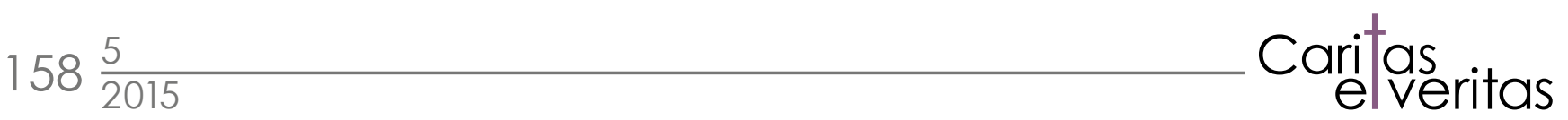

tions are ensured as will enable them to fulfil the values of social work they acknowledge in organizations where they work or for which they work." 22

This attitude is commonly criticized as a manifestation of the wilfulness or professional pride of social workers. Criticism points out that social work is not "... defined by its legal framework, but by what it in fact does, one would almost like to say: what it claims by it factual care." ${ }^{23}$ In fact it is overlooked, if not ignored, that defence of the professional interests of social work on the part of social workers is not determined by their wilfulness but by the contemporary social context: "In the postmodern perspective of institutionalized social work - which derives from the individualized identities of social workers, fragmentary notions of individuals and by them constructed discourses of (concerning) social work, and therefore also the constructed notions of the professional interests of social work - the professional freedom of the individual social workers in organizations takes the form of the necessary presupposition without which institutionalization of social work would not be possible. ${ }^{24}$

The contemporary situation when social work is realized in organizations financed through the system of social services therefore has at least two paralyzing effects on social work:

- As already described above (see point 1.2) in this situation it is not in the interest of the assisting organizations to defend their clients and request change on the part of their social environment. Organizations are afraid to defend their clients because they are dependent on those who decide about the financing of social services. ${ }^{25}$ If this decision-making instance is of another opinion, normally that the problem is on the part of the client, organizations do not want to contradict this opinion in the interest of their own financing. That the one who eventually gets most beaten in this is the client of social work need not even be added (see point 2).

- Introducing the system of social services has brought along market mechanisms. These are naturally justified; e.g. when the client of a nursing service in a bigger city can choose which organization will provide this social service to her. Thereby the role of the client is strengthened and at the same time pressure is exerted for quality providing of the social service. But a different situation arises in case social services are provided based on the submitter's (regional office, magistrate, municipal office) commission. Several organizations working with the same or similar clients thus fight for one money package. It can be e.g. a low-threshold facility for children and youth and a civic consulting facility, i.e., two different services working with clients of one and the same socially excluded locality, or even with clients from one and the same family. To this competition between social services providers and public administration is added. ${ }^{26}$ The setbacks of market principles affect the client here as well. But she does not profit from this competitive struggle because she has come to be regarded by the organizations only as a means in their mutual fight for survival.

Precisely for these reasons the feeling of loss of meaning and identity of social work appears. Based on these reasons it therefore at the same time appears important that social workers

\footnotetext{
22 Roman BALÁŽ, Možnosti dosahování oborových zájmů, p. 45.

23 Jakub JINEK, Sociální spravedlnost, p. 38.

24 Roman BALÁŽ, Možnosti dosahování oborových zájmů, p. 52. Cf. also Libor MUSIL, Challenges of Postmodern Institutionalisation, pp. 10-72.

25 Cf. Roman BALÁŽ, Možnosti dosahování oborových zájmů, p. 56.

26 Cf. Radka JANEBOVÁ - Marcela HUDEČKOVÁ - Romana ZAPADALOVÁ - Jana MUSILOVÁ, Příběhy sociálních pracovnic a pracovníků, p. 67.
} 
defend the professional interests of social work. For defending them, or social workers' negotiating about the professional interests of social work, forms their identity; it defines their social role and borders with respect to other assisting professions. ${ }^{27}$ This defence is not to take place on the line between social workers and the state or local administration - as might appear at first sight - but at the level within the assisting organization.

The crucial question of organizations employing social workers should be how to - from the point of view of the organization and its (social) workers - suitably balance out the duality of required responsibility to organization rules and freedom of decision, or independent exercising of the social worker's will. It is possible that social workers regard negotiation as legitimate (postmodern trend), while organizations expect rather assertion (modern trend). As a consequence this means that organizations are not at the moment prepared to accept the postmodern conception of social work, which may be due to the fairly common phenomenon that individuals and groups react to changes faster than social institutions and their organizations. ${ }^{28}$ From this situation further again stems the feeling of loss of meaning or even identity of social work in social workers, who as a result feel that they are stressed more by the context of their work than the problems of their clients (see point 1.2).

As the preceding three points have shown, reflections on the blurring of social work's identity and efforts at re-finding or re-grasping it are to a great extent enclosed in a self-centred circle. In other words, social work takes more interest in itself than it does in the ones it should primarily be interested in, i.e., its clients. The answer to the question concerning the identity of social work and its meaning need not necessarily be looked for in social work itself. Above we have repeatedly recalled that the contemporary crisis or misery of social work ultimately affects first of all the clients of social workers. But precisely on them social work is aimed and it therefore seems necessary to look for the meaning of social work or source of its identity with its clients.

\section{The meaning of social work and its client}

A view of the situation of social work similar to the one outlined in point 1 can be encountered for already a number of years in professional discourse concerning social work in foreign literature. ${ }^{29}$ According to Silvia Staub-Bernasconi, in the contemporary public and professional discussion concerning social work three different positions from which social work is viewed can be noted. They are points of departure from which not only social work itself but also other academic fields, segments of the state and components of society create their own theories concerning social work. Staub-Bernasconi designates the first two positions as extreme:

- Within the first position promotors of civic society assert the idea of volunteer help, because everyone can help.

- The second position is taken by those who view the world economically. Their view of social work is that it is to fulfil certain tasks which the organization has defined, and to contribute to economic growth as a result.

27 Cf. also Libor MUSIL, Challenges of Postmodern Institutionalisation, pp. 33-34.

28 Cf. Roman BALÁŽ, Možnosti dosahování oborových zájmů, pp. 51-56.

29 Cf. e.g. the almost ten years old German paper: Martin ALBERT, Die Ökonomisierung der Sozialen Arbeit, Sozial Extra 7-8/2006, pp. 26-31. 
- Between these two poles there oscillates a third view of social work which sees it as some sort of assisting power - assisting with respect to doctors, nurses, psychologists etc. $^{30}$

Of course this holds more in the German-speaking context than it does in the context of CR, where the first version of conceiving social work rarely appears, while its third conception is on the other hand relatively widespread (see point 1). ${ }^{31}$ But regardless of the local and cultural differences these views according to Staub-Bernasconi have one quite fundamental defect: they overlook the needs of the human being - i.e., the social worker's client. Expressed differently, they only deal with the social function of social work. The second and third approach sees social work as correcting the society or supplementary activity which is to support the work of the "real" assisting professions. What is the client's problem and why the client is struggling with the problem falls out of the perspective of both conceptions of social work. Similarly in the first case mentioned by Staub-Bernasconi, because the notion that there is no need for professional social work can only arise out of a lack of knowledge of the problems that social workers' clients must solve in their lives.

Staub-Bernasconi's harshest criticism is aimed at the orientation on the social function of social work, which is at present most widespread and manifests itself by realizing social work within the system of social services. It is therefore criticism of a system known not only in the German-speaking countries but also in CR, as described above (point 1). Here it is according to Staub-Bernasconi necessary to state that the point of departure of the indicated approach to social work is a "bird's eye view" of the society. That is why it starts from the socially general and asks about individuals who can threaten the stability of social systems. Thus there arises "orientation on the client", which social work takes over from company economy and which in fact solves nothing because the addressee of social work is viewed as a resource to be extracted by being (re)enabled to enter the market mechanisms in society. From this perspective it also appears logical that there exist trends and approaches in social work which do not think of the client's environment as the primary source of her problems at all (see point 1.1). The "advantage" of this approach is distancing oneself from human suffering, social work theory need not deal with it because it only asks what to do with an individual so that the systems of which she is an element function well. ${ }^{32}$ Creating theories of social work then consists in systematically suppressing theories aimed at the needs of the addressee of social work, the so-called "vulnerable human", by theories aimed at the functioning of society and its social systems. The approach oriented on the social function of social work further gradually becomes an element of culture: "One is tempted to speak of the rise of 'mental apartheid towards human need' - at local, national and supranational level." 33

Orientation on the needs of the addressee of social work is thus in this context denounced as orientation on deficits. ${ }^{34}$ Of course in case when we according to Staub-Bernasconi orient ourselves precisely on the needs of the human being, the reasoning will go "from bottom up" i.e., from the individually specific to the socially general. In such case the starting question is not e.g. whether someone is poor or commits crime, but who is vulnerable. Only when this question is answered in theory and practice is it possible to ask about the function of social work, with

30 Cf. Silvia STAUB-BERNASCONI, Soziale Arbeit als Handlungswissenschaft: systemtheoretische Grundlagen und professionelle Praxis ein Lehrbuch, Bern; Stuttgart; Wien: Haupt, 2007, pp. 12-14.

31 Cf. also Mirka NEČASOVÁ, Profesní etika, in: Metody a řizení sociální práce, ed. Oldřich MATOUŠEK, Praha: Portál, 2003, p. 40.

32 Cf. Silvia STAUB-BERNASCONI, Soziale Arbeit als Handlungswissenschaft, pp. 125-129.

33 Ibid., p. 129.

34 Cf. ibid., p. 149. 
respect to its addressees and with respect to the society and the trustees or operators of social services facilities. According to Staub-Bernasconi it is nonetheless possible to imagine that both approaches (models) will be complementary, because it is necessary to see both the micro-level of the individual and her needs and the macro-level of the society and its functioning. Only when the approach aimed at the social function of social work is abandoned and replaced with orientation on the needs of the human being will it be possible to resume it so that the two models can become complementary. ${ }^{35}$

\section{Evaluation}

Silvia Staub-Bernasconi's view of the contemporary problems of social work in fact makes practical use of Kant's ethics: "Kant's universal categorical imperative in a particular case means that in acting one ought to think of others, or for them." In order for this requirement to be fulfilled "... it is necessary that everyone thinks from the position of the weakest or most vulnerable member of society, to think for her, or put differently, think of her." 36 That is why this view can be generalized in the sense that it can be valid in the Czech context, or in the Czech conditions of realizing social work. It is characteristic of this context that it to a great extent fends precisely this view off by the assisting organizations' manner of functioning (see point 1.3) because they are financed by means of social services (see point 1.2), which pushes them to efficiency (see point 1.3). As a consequence social work is viewed from the socially general to the individually specific (see point 2). One could almost say that over the past quarter of a century the view of social work has practically not changed, when it still prefers the majority to the individual.

Fortunately for social work this view is taken primarily by social policy, i.e., party policy which forms social policy at state and regional level (see point 1.2). The professional discourse of social work itself takes critical distance from this view, ${ }^{37}$ which is why the mentioned conflict situations arise. The expected set of knowledge and competencies of social worker thus fortunately still quite matter-of-factly assumes that the meaning of social work is helping the client. Besides knowledge, or even more than knowledge, the worker needs skills by means of which she will be able to fulfil this task..$^{38}$

The primary question of social work proposed by Staub-Bernasconi, i.e., who is vulnerable, thus converges with the present call of the professional discourse of social work for responsible consideration of whether the cause of the client's problems is on her part or on the part of her social environment. In the context of psychosocial crisis assistance and cooperation, which in this country seems to be built more on principles of social work than psychological support, ${ }^{39}$ it is thus common to think of the causes of the client's vulnerability, as well as of the resources for empowering her in the social context: "Vulnerability is and always has been a consequence of social and economic differences. The ability to recuperate therefore comprises social, cultural, ideological, political - as well as economic aspects." Vulnerability "... decreases if good economic and social development, healthy family and social structures, good government, estab-

\footnotetext{
35 Cf. ibid., pp. 120-131.

36 Cf. Jindřich ŠRAJER, Sociální spravedlnost jako základní kritérium sociální práce a sociální politiky, Sociální práce/Sociálna práca 4/2014, p. 78.

37 Martin SMUTEK, Sociální politika a sociální práce, in: Encyklopedie sociální práce, ed. Oldřich MATOUŠEK et al., Praha: Portál, 2013, pp. 166-167.

38 Cf. Martina PAJMOVÁ - Markéta ELICHOVÁ, Role osobnosti a edukace, pp. 105-107.

39 Cf. () Ministerstvo vnitra, Standardy psychosociální krizové pomoci a spolupráce zaměřené na průběh a výsledek (on-line), at: www.hzscr.cz/ soubor/standardy-pskps-prosinec2010-pdf.aspx, actualized in December 2010, retrieved on March 2 ${ }^{\text {nd }}, 2015$.
} 
lished regional and national networks, participative community structures and management, opportune infrastructure of services and material environment prevail in the community..." 40

With respect to this it therefore appears necessary that the very functioning of social work is subsidiary in character - so that social workers can defend the professional interests of social work (see point 1.3). But this at the same time requires that the social policy context of realizing social work is set up in a similarly subsidiary manner. If the efficient cause and end of every social institution is the individual human being, then every social activity must logically be subsidiary in essence. ${ }^{41}$ Only the orientation of social work on its client together with the same orientation of the external framework of social structures including social policy makes it possible not only to search for an answer to the question who is vulnerable, but also that it can be raised at all. But this view is not "in vogue" in the present Czech context (see point 1), so that it can in fact be said that social workers' negotiation with organizations and the state and its components concerning the professional interests of social work is in a way a fundamental part of the discussion of democratic principles in society and state. ${ }^{42}$

\section{Conclusion}

With respect to what has been stated it is therefore possible to say that some contemporary professional and lay opinions which try to assert the socially general to the detriment of the individually specific in fact in a way pose a threat to discussion concerning the democratic ordering of society. Insofar as they concern social problems and social work they even contradict the very meaning and identity of social work. Withdrawing the right to decide about their children from parents, ${ }^{43}$ denying the advantages of inclusive education, ${ }^{44}$ or even proposing to withdraw the right to life from children ${ }^{45}$ only based on their state of health thus not only appears to be incompatible with the very meaning of social work but directly threatens the democratic structures in society.

If social work is to a great extent defined only indeterminately, as it has been so far (see point 1.1), we must reckon with unclarity in the identity of social workers. ${ }^{46}$ On the other hand, strengthening the aiming of social work at its clients in the spirit of the question that the one who is the most vulnerable needs help strengthens the democratic structures of the state and society. In this context it is worth mentioning that this question is in fact an ancient principle governing the Judeo-Christian conception of social work. ${ }^{47}$

\footnotetext{
40 Karel ŠIMR, Neštěstí, náboženství a duchovnost, in: Psychosociální krizová spolupráce, ed. Bohumila BAŠTECKÁ, vyd. 1., Praha: Grada, 2013, p. 91.

41 Cf. Jindřich ŠRAJER, Sociální spravedlnost, p. 78.

42 On the issue of relationship of social state and democracy cf. Martin SMUTEK, Sociální stát, in: Encyklopedie sociální práce, ed. Oldřich MATOUŠEK et al., Praha: Portál, 2013, p. 163.

43 Cf. Miroslav MITLÖHNER, K právním a etickým problémům spojeným s narozením těžce malformovaného jedince, Časopis zdravotnického práva a bioetiky 1/2014, pp. 48-54 (on-line), at: http://www.ilaw.cas.cz/medlawjournal/index.php/medlawjournal/article/view/64, retrieved on March $2^{\text {nd }}, 2015$.

44 Cf. @ ECHO24.CZ, Další Zemanův skandál. Poslanci se bouří, Chládek chce jít na Hrad (on-line), at: http://echo24.cz/a/wKTmz/dalsizemanuv-skandal-poslanci-se-bouri-chladek-chce-jit-na-hrad, actualized on January 1 ${ }^{\text {st }}, 2015$, retrieved on March $2^{\text {nd }}, 2015$.

45 Cf. Miroslav MITLÖHNER, K právním a etickým problémům, pp. 48-54.

46 Cf. Martina PAJMOVÁ - Markéta ELICHOVÁ, Role osobnosti a edukace, p. 108.

47 Cf. Stephanie BOHLEN, Teologie a sociální práce - podněty pro dialog, in: Teorie a praxe sociální práce: Uvedení do problematiky, Praktická reflexe a aplikace, ed. Michal OPATRNÝ - Markus LEHNER, České Budějovice: Teologická fakulta Jihočeské univerzity, 2010, pp. 32-33; Michal OPATRNÝ, Charitativní práce: interakce sociální práce a diakonie, in: Teorie a praxe sociální práce: Uvedení do problematiky, Praktická reflexe a aplikace, ed. Michal OPATRNÝ - Markus LEHNER, České Budějovice: Teologická fakulta Jihočeské univerzity, 2010, p. 44.
} 


\section{Return to the Client: On the Contemporary Search for the Meaning of Social Work}

Abstract The study discusses the search for meaning and position of social work in postmodern social context. At present there is talk in social work of crisis and failure of social work, which consists in the blurring of its identity, the fact that social work is carried out by unqualified workers, and loss of social prestige. In the contemporary professional discourse of social work in the Czech Republic the study first identifies three areas from which the loss of meaning and threat to the identity of social work stem (definition of social work, system of social services, real conditions of carrying out social work). Based on reflecting these areas the study states that the discourse concerning the identity and meaning of social work loses sight of the client of social work. That is why it briefly summarizes the conception of social work in Silvia Staub-Bernasconi, who in defining social work emphasizes the question "Who is vulnerable". On this basis the study then concludes that further defence of the professional interests of social work in public discourse and in the context of social services providers is needed, which as its goal will pursue not a general question of the identity of social work but the good of its client.

Keywords social work, identity of social work, social policy, social services, social state 